\title{
CHINA-PAKISTAN ECONOMIC CORRIDOR (CPEC) ENERGY PRIORITY \& OPTIONS FOR SINDH
}

\author{
Nighat Moin \\ Assistant Professor, \\ Indus University, Karachi \\ \& \\ Dr. Suwaibah Qadri \\ Assistant Professor, \\ Department of Political Science \\ University of Karachi, Karachi. \\ suwaibaha@gmail.com
}

\begin{abstract}
The significance of China for Pakistan can actuate further by the economic partnership \& commercial interest through the connectivity via CPEC. The exigent deep-sea maritime port (Kashga-Gwadar port) is financed \& operated by china provides Pakistan with ample opportunity to paramount commercial relations with Central-Asia republics. Furthermore, Pakistan reveals the prospect of symbolic transit fees; an opportunity to Pakistan public finance. The whole project would take at least 15-20 years for completion \& if carried forward in an uninterrupted way, Pakistan would earn huge amount of dividends in long-run, because CPEC project worth estimated $\$ 32$ billion would be financed by FDI through Chinese companies; hence not borne by Pakistan \& the remaining $\$ 12$ billion investment is by government to government loans. CPEC project will increase the employment opportunities into the backward district of Pakistan via providing the infrastructure \& connectivity with the rest of the world especially the central-Asia, which entertain Pakistan economy in a win-win situation by stabilizing the economy politically \& economically. Further, Chinese imperatives with CPEC project can be expedite with the observations that CPEC will reduce the distance \&
\end{abstract}




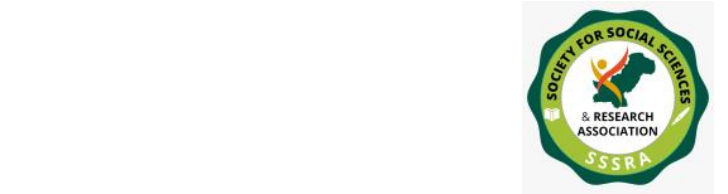

China - Pakistan Economic Corridor ......

provide China an ease of oil supply via land-based oil supply port between Pakistan \& China.

This paper is reviewing \& analyzing the CPEC Sindh-based projects especially in the areas of energy generation which are expected to be completed by 2020. It is also highlighting the importance of the Sindh province \& determining the importance of the hub of Pakistan trade \& the major contributor of Pakistan revenue that how the development in the province will leads to the development \& growth of rest of the provinces of Pakistan. On another hand Chinese imperatives with CPEC project can be expedite with the observations that CPEC will reduce the distance \& provide China an ease of oil supply via land-based oil supply port between Pakistan \& China.

Keywords: CPEC, Energy, Trade, Development, Sindh.

\section{INTRODUCTION}

In 2013 the policy approved by National Power Policy to combat the power challenges $\&$ to achieve the long-term sustainability. In the project of CPEC the estimated financial outlay of energy is US\$ 13.27 billion which include power generation \& transmission projects. Within the territory OF Pakistan, the CPEC corridor will be around $2000 \mathrm{~km}$ long. The main routes of CPEC are: Kashgar-Hunza -Chilas-MansehraAbotabad-Islamabad-Miyanwaki-Dera Ghazi Khan-khuzdar-HoshabGwadar. Huge sacrifices has made by Pakistan to reduce terrorism all over the world and proved Pakistan's independence, territorial integrity is ensured with respect nationally and on international level. In addition Pakistan tried so fierce to get admitted in international community for her contributions and efforts to maintain domestic stability and to realize economic and social development. Karachi is the hub of trade \& generate major portion of National Income. Lahore-Karachi Motorway is an imperative of this corridor. Pakistan signed MoU in July 2013 under the Ministry of P\&D \& CSCEC to complete this motorway within three years (The News 2013). Further we can observe that Karachi in this way will get connected further via two routes named Makran Coastal Highway (National Highway) which is viable since 2003, \& another named Khuzdar 
(National Highway N25) \& Hoshab (National Highway N85) \& Motorway M8.

In order to carry oil via pipeline from the Middle East to China's western regions which is buttoned up the port of Gwadar is also planned \& included IP gas pipeline project in CPEC corridor project. Gwadar is going to be developed as a FTZ on the lines of Hong kongor Dubai \& splint it with Kashgar EDZ, already backed \& being developed by China. (Husain, 2017, June 12). During 2014, Pakistan's Prime Minister sojourn to China for the distinct agreement signed with China included these to erect; i. The Gwadar New International Airport, ii. Gwadar Eastbay Expressway \&, iii. A technical \& Vocational Training Institute in Gwadar.

CPEC is also pertinent with the approval of numerous projects worth US\$ 28 billion in addition to its direct benefits, traverse most provinces \& suburb of Pakistan, among the few ones are;

a. CBPP at Port Qasim (Karachi, Sindh).

b. A WPP at Jhimpir (Sindh).

c. Gwadar-Nawabshah LNG terminal \& pipeline project (Baluchistan-Sindh)

d. Laying of Optic Fibre between two countries.

Among all the projects few are early Harvest \& others are long term projects. But among all he projects most of CPEC project proclaim energy (US\$ 3.8 billion) \& connectivity via underpinning (US\$ 11.8 billion). CPEC is supposed to revamp Pakistan into a parochial trade core $\&$ energy carrying corridor, by greatly immense transit revenues on one hand \& making his corridor a pivot an another hand; which will leads to huge brunt on industrial, agriculture \& overall economic growth \& development of Pakistan.

CPEC project is also indispensable to China by developing its western 


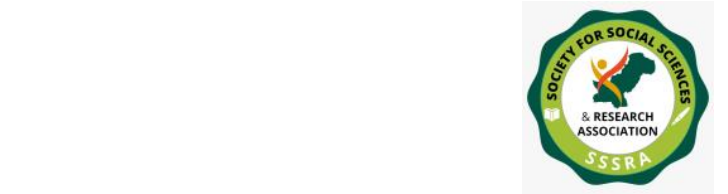

China - Pakistan Economic Corridor $\ldots . .$.

parochial \& augment its relations with Southern countries, Central \& Western Asia (PRC MOFA 2015), \& the oil pipeline from Gwadar to China will remove the infringement of piracy related with the existing route of oil imports passes through the Malacca \& cater an ease to import oil from Middle-East to China. The population of Sindh according to 1998 census is 23.00 millions. Sindh has very strong cultural and Economic background. The province also highlighted very civilized economic condition in the past. Therefore, it is important to give priority to the Province on the basis of its sound economic background and heritage. Further, Karachi, as a capital city of Sindh, needs to be facilitated on the priority basis as this city is major economic contributor for the GDP of Pakistan since the Pakistan came into existence. But as far as basic needs of this city is concerned it is evident that nonetheless any ruling government accentuate on its due requirement by the State side. The civics of Karachi is supposed to be the advancement of the remaining provinces directly and indirectly all the time, plus enhance the trade of Pakistan for improving the Real GDP \& new opportunities for further macroeconomic changes.

\section{$1^{\text {st }}$ Project}

The project is of 2X660 MW coal-fired power plants at Port Qasim Karachi, Sindh comprised of 1320 MW \& the estimated cost is US \$ 1980 million. This projects primary energy input is coal which is to be import \& using super critical technology. Port Qasim Electric power company (Pvt.) Limited is executing this project in collocation with the ministry of water $\&$ power under the supervision of PPIB. Initiatives have been taken by achieving FC \& civil entirety on site is commenced in May, 2015 but the COD is expected in June 2018.

\section{$2^{\text {nd }}$ Project}

The $2^{\text {nd }}, 3^{\text {rd }} \& 4^{\text {th }}$ CPEC Sindh Projects are Engro Thar Block II 2 X 330 MW CFPP, TEL $1 \times 330$ MW MMLF Power Project at Thar Block-II, Sindh, Pakistan \& Thar Nova $1 \times 330$ MW MMLF Power Project at Thar Block-II, Sindh, Pakistan. These three Projects are also of immense contributions to the Sindh \& comprised of 660 MW, 330 MW \& 330 MW 


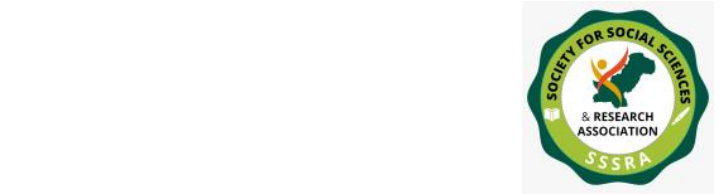

respectively \& the estimated cost of the three Projects is US\$ 2000 million collectively.

\section{$3^{\text {th }}$ Project}

The next is the Surface mine in block II of Thar Coal field, which is an Open Pit Mining Project in Sindh \& the estimated cost of this project is US\$ 1,470. CMEC / SECMC is executing this Project in codification along Ministry of $\mathrm{W} \& \mathrm{P} /$ Ministry of $\mathrm{P} \& \mathrm{NR}$ under the supervision of TCEB. The Project's FC is consummate \& signed by IA/IE \& the depth of $76 \mathrm{~m}$ is achieved. The COD is expected in 2018/2019.

\section{$4^{\text {th }}$ Project}

The Hydro China Dawood 50MW Wind Farm (Gharo, Thatta) Project is also in Sindh with installed capacity of $50 \mathrm{MW} \&$ the estimated cost of US\$ 125 with Primary Energy Input of Wind by using wind turbine. The company which is executing this project is M/s HDPPL \& the project is financing by IPP in coordination with Ministry of W\&P under the supervision of AEDB. The FC is achieved for this Project on 2015 \& COD acquired 5th April, 2017 \& now the project is operational.

\section{$5^{\text {th }}$ Project}

The UEP 100MW Wind Farm (Jhimpir, Thatta) Project in Sindh with Wind Turbine is also another blessing for the Sindh. This Project's estimated cost is US\$ 250 million \& the executing company is Hydro China (EPC) Gold Wind China (Supplier) / United Energy Pakistan (Pvt.) Ltd The project is financing by IPP in coordination with Ministry of W\&P under the super vision of AEDB. This project has achieved FC in 2015 \& COD is acquired in June 2017 \& now the project is operational.

\section{$6^{\text {th }}$ Project}

Another Sindh Project is Sachal 50MW Wind Farm (Jhimpir, Thatta) with installed capacity of $50 \mathrm{MW} \&$ the estimated cost is US\$ 134 million. The executing company is Hydro China / Arif Habib Corporation Limited \& the Project is financing by IPP in coordination with Ministry of W\&P under the supervision of AEDB. This project has achieved the FC in 2015 $\&$ attained the COD in 2017 \& now it is operational. 


\section{$7^{\text {th }}$ Project}

The SSRL Thar Coal Block-I $7.8 \mathrm{mtpa} \&$ SEC MMPP $(2 \times 660 \mathrm{MW})$ Project main source of primary energy input is coal with the capacity of $1320 \mathrm{MW} \&$ the estimated cost is US\$2,000 + 1,300. The Project is executing by SEPC Ltd. / CCTEG and SSRL \& financing by IPP in coordination with Ministry of W\&P under the supervision of PPIB \& the COD 2018/2019.

\section{$8^{\text {th }}$ Project}

Three Gorges Second WPP \& Three Gorges Third WPP also belong to Sindh with Primary Energy Source of Wind by using Wind Turbine with the installed capacity of $50 \mathrm{MW}$ for each. The estimated cost is US\$ 150 . This venture's LOS issued in August 2016 \& the EPA initiated in November 2016. This Project's construction activity already evoked from equity \& also attained FC in March 2017. This Project the COD $2018 / 2019$.

\section{$9^{\text {th }}$ Project}

Matiari To Lahore $\pm 660 \mathrm{kV}$ HVDC TLP is used $\pm 660 \mathrm{KW}$ Bipole HCDC with Converter/ GES with the capacity of $2000 \mathrm{MW}$ with $10 \%$ overloaded potential for 2 hours. The estimated cost is US\$ 1500 million \& CET / SGCC is executing this Project $\&$ it is financed by ITC in coordination with Ministry of W\&P under the supervision of NTDC. This project feasibility consideration is built $\&$ its tariff is resolute by NEPRA. The land procurement for converter stations at Lahore \& Mitiari is built \& COD is $2018 / 2019$.

\section{$10^{\text {th }}$ Project}

Matiari (Port Qasim) - Faisalabad Transmission Line Project is using the \pm 660 KW Bipole HCDC with Converter/ GES technology with the capacity of $2000 \mathrm{MW}$ with $10 \%$ overburdened capability for 2 hours. The approximated cost is US\$ 1500 million. The Project is executing by CET / SGCC \& financing by ITC in coordination with Ministry of W\&P under the direction of NTDC. Feasibility study of this Project is completed \& decision on Tariff review petition is declared by NEPRA \& COD is 2018/2019. 


\section{$11^{\text {th }}$ Project:}

Thar MMOPP (1320MW) \& SMP Primary source of Input is Thar Coal with installed capacity of $1320 \mathrm{MW} \&$ the estimated cost is US\$1,300 million. The company executing this Project is M/s Oracle Coalfields SEPCO and Yanzhou Coal \& the Project is registered with PPIB.

Sindh Energy Schemes (Ongoing)

Total (Energy ongoing schemes)

Estimated cost is Rs. 4074.000 million.

Allocation for 2017-18 is Rs. 1300.000 million.

Final Projection 2018-19 is Rs. 35.355 million

Final Projection 2019-20 is Rs.000 (Nil)

\section{Sindh Energy Schemes (New)}

Estimated cost is Rs. 6810.000 million.

Allocation for 2017-18 is Rs. 1705.000 million.

Final Projection 2018-19 is Rs. 2552.500 million.

Final Projection 2019-20 is Rs. 2552.500 million.

\section{Total Energy Schemes}

Estimated cost is Rs. 10884.000 million.

Allocation for 2017-18 is Rs. 3005.000 million.

Final Projection 2018-19 is Rs. 2587.855 million.

Final Projection 2019-20 is Rs. 2552.500 million.

\section{Thar Coal: The Gateway to Energy and Security of Pakistan}

Pakistan energy requirements potentially huge:

- Sixth largest country in the world, with its growing population to exceed $190 \mathrm{~m}$ by 2015 . 
- Rising population, incomes, per capita energy use, and industrialization translate to high energy demand growth (total primary energy supply expected to triple or quadruple by 2025).

- Serious economic and development implications, as energy deficit Pakistan faces increasing energy import cost, with few medium term solutions to supply shortfalls

\section{Apprehension}

The comparison of the projected demand figures with the total current firm supply figures of our country can be obvious by the gravity of the situation.

Current Installed ----17897 (MW)

$\begin{array}{lcc}\begin{array}{l}\text { Projected } \\ \text { (MW) }\end{array} & \text { Pemand } & \text { Gap (MW) } \\ 24,474 & 2010 & 6,577 \\ 36,217 & 2015 & 18,320 \\ 54,359 & 2020 & 36,462 \\ & & \\ 80,566 & 2025 & 62,669 \\ 1,13,695 & 2030 & 95,798\end{array}$

\section{Load Shedding Worth Nationwide}

Worth to the Industrial Sector

---Rs 157 billion

Worth to the other sectors of industrial damage of Value Added

------ Rs 53 billion

Total worth of industrial load shedding to the economy

---Rs 219 billion

Worth as percentage of GDP

$----2 \%$

Damage of employment in the economy

$------400,000$ 
Damage of exports

Rs 75 billion

billion)

\section{Flipside}

(Equivalent to US \$1

Continue Importing Furnace Oil leading to increasing import bill.

- The need is to revamp and pinpoint Alternate/Renewable Energy

- Develop Hydel Projects

- The losses to $T \& D$ need to be minimized via efficiency improvement amplification.

- Concentrate

- Beware the exploited indigenous resources, such as Thar Coal which has a generation potential of 100,000 MW consuming 536 million tonnes / year (Enough resources for more than three centuries).

- Beware of total reserve is equivalent to 50 billion tone of oil (more than Iran and Saudi Arabia combined oil reserves) or over 2000 TCF of Gas (42 times greater than total gas reserves discovered in Pakistan so far)

\section{Pakistan's Coal Reserves}

Sindh

Punjab

185,457 million tones

Balochistan

235 million tones

NWFP

217 million tones

90 million tones

Comparison of Stripping Ratio, Healthy Value \& Generation of Lignite in other Countries 
Neyvelli lignite 7:1

Heating value $=5200 \mathrm{Btu} / \mathrm{lb}$

Total generation $=2,740 \mathrm{MW}$

Lignite 6:1

Heating Value: $6200 \sim 11,000 \mathrm{Btu} / \mathrm{lb}$

Total generation $=0 \mathrm{MW}$

Comparison of Stripping Ratio, Healthy Value \& Generation of Lignite in other Countries

India

Neyvelli lignite 7:1

Heating value $=5200 \mathrm{Btu} / \mathrm{lb}$

Total generation $=2,740 \mathrm{MW}$

\section{Germany}

Rhineland lignite 4.9:1 (m3:t)

Heating value $=4,514$ to $11054 \mathrm{Btu} / \mathrm{lb}$

Total generation $=10,289 \mathrm{MW}(\mathrm{m} 3: \mathrm{t})$

Heating value $=3,035 \mathrm{Btu} / \mathrm{lb}$

Total generation $=1,852 \mathrm{MW}$

\section{Hungary}

Hungary lignite 9:1 (m3:t)

Heating value $=3,035 \mathrm{Btu} / \mathrm{lb}$

Total generation $=1,852 \mathrm{MW}$

\section{Thar Coal}

Lignite 6:1

Heating Value: $6200 \sim 11,000 \mathrm{Btu} / \mathrm{lb}$

Total generation $=0 \mathrm{MW}$ 


\section{Electricity (KWH)}

Per Capita Electricity Generation 2009-10

\author{
Gas (Cubic Meter) \\ Per Capita Gas Consumption \\ 2009-10
}

252.24

\section{8-09}

548.68

526.67

2008-09

257.50

\section{REVIEW OF LITERATURE}

In the study of Zhiqin and Yang (2016), CPEC project is a landmark between the relations of China and Pakistan. It seems to be a large-scale moxie to build energy, highway, and port infrastructure to strengthen economic association between China and Pakistan. This project was first proposed by China in May 2013 and both the nations got agreed in April, 2015.The opening ceremony of CPEC project was held in Sukker, Pakistan on May, 2016. The ministry of PDR, GoP states that Pakistan aims to advance from LMI country to an UMI country till 2025. In order to achieve this target the economy requires energy projects and multisectoral cooperation in finance, trade, energy and other reforms. The fundamental of CPEC project is the formation of estate which is supposed to be an extraordinary economic zone. According to Pak-China News (2016) CPEC project initiated in 2014 would be completed by 2030.

According to Husain (2017, June 12), the special economic belt formulation is a crucial component of this project via establishment of industries, which is facilitated by availability of water, appropriate infrastructure \& energy supply for effective completion of the project \& 


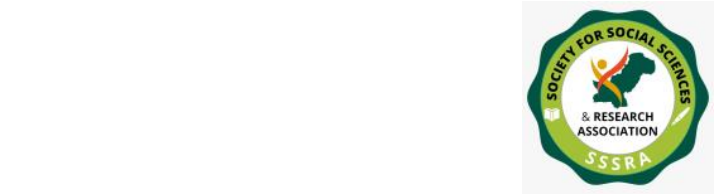

China - Pakistan Economic Corridor $\ldots . .$.

achieve the main target of connecting Xinjiang \& Pakistan. The project includes a 'Core Area' and a 'Radiation Zone', including 'Kashgar, Tumshuq, Atushi, and Akto of Kizilsu Kirghiz of Xinjiang” of China and Islamabad, Punjab, and Sindh, and some areas of Gilgit-Baltistan, Khyber Pukhtunkhwa, and Balochistan" of Pakistan respectively. The project also comprised of Meat processing plants with annual capacity of 200,000 tons per year and two demonstration plants processing 200,000 tons of milk per year. CPEC plan confront a telluric cable across the Khunjerab pass to Islamabad, and a submarine landing station in Gwadar, linked to Sukkur, as there are four submarine cables to knob internet traffic but there exist security risks due to the existence of only one landing station.

According to Rafiq (2017), the successful completion of the first phase leads to further 100 billion USD ready investments. The overall project meets the Pakistan's longing of vision 2025 by tracking the economy towards well-being. The Chinese manufacturers will facilitate the industrial zone of CPEC as it will be tax free and back by government of China with finance with huge finances. The products traded will be of lower-cost with almost 30 percent less due to free zone ports such as Dubai \& Doha, then definitely embark the trade to go for purchase via CPEC trade zone. As stated by Dilawar, I. (2017, April 13), 17,000 and more Pakistani security personnel are working with the task of protecting Chinese nationals staying in Pakistan under the umbrella of CPEC. According to Husain, (2017, June 12). satellite monitoring is also in progress regarding CPEC projects and expected to be launched in June, 2018.

The study of Dilawar, (2017, April 13) the backbone of financial structure of Pakistan is Karachi, as it has two seaports which lead to its path to Central Asia, Africa, Europe, \& China. The study stated that CPEC includes various energy \& transport infrastructure projects including 2 Sindh based projects out of 10 transport projects. Further he said that the power producing by Sindh via Thar coal and Bin Qasim is being utilized by Punjab. The scarcity of quality water for Sindh is still a big deal for the people of province earning 70 percent of the total revenue for Pakistan. CPEC is will bring employment opportunities and development for 


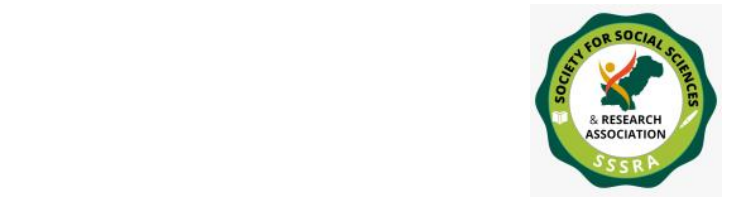

Pakistan and especially for Sindh \& Baluchistan. According to Associated Press of Pakistan, (2016), the CPEC comprised of US \$ 35 billion energy components which would be a healthy sign for the solution of the energy crises in Pakistan. According to the Ministry of PDR, Government of Sindh, among these projects of CPEC energy components, Sindh province is the largest recipient with US\$ 11.5 billion out of US\$ 35 billion energy portfolio. Further two power plants with the capacity of 10,000 MW and 15,000 MW will be the part of CPEC energy projects by 2018 and 2025 respectively.

A press release by Rafiq, (2017) China approved three major projects for Sindh province with the cost of multi-billion dollar. Karachi circular Railways, Keti Bandar and Dhabeji SEZ are among them. According to Khan, Khan, \& Anwar, (2016)Cooperation Committee (JCC) meeting in 2016 held in Beijing, China, it was suggested to include Khairpur SEZ but got rejected because of the fact that only one SEZ will be given to one province therefore accepted only Dhabeji SEZ of Sindh \& highlighted that the ongoing energy projects under CPEC will be completed by 2017-18. China expect to invest more than $\$ 46$ billion in energy and infrastructure venture in Pakistan till 2017-18, comprised of Lahore-Karachi Motorway, Karakorum Highway and expanding the extent of Gwadar port. It includes equal perk for all the provinces. Sindh's two major ventures are MultanSukkur project and Karakorum Project from Havelian to Thakot.

According to PEPCO, Government of Sindh, Pakistan , (2012). Sindh is the leading province of Pakistan to have honored special economic zones, Bin Qasim Industrial Park, Korangi Creek Industrial Park and Khairpur Special Economic Zone. Karachi is the most colonized city of the world, approximated in 2016 for about 25.1 million. This population is more than Tokyo, Guangzhou, Seoul, Delhi, Mumbai, Mexico City, New York, Sao Paulo, Manila and Jakarta \& estimate to surge more and grasp for about 34.3 million in 2030. The project of Keti Bandar, Chief Minister, Sindh highlighted the matter that Pakistan's coastline is more than 1,000 kilometres long. As stated by Chief Minister of Sindh in a press release by Ali, S. (2016, December 30) it has three extensive ports, Karachi, Bin Qasim and Gwadar. In addition to these, keti Bandar is an 


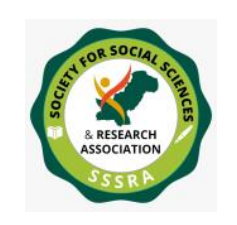

Pak. Journal of Int'L Affairs, Vol 3, Issue 1 (2020)

China - Pakistan Economic Corridor $\ldots . .$.

exemplary region to nurse as Thar coal-based power park and a significant port for ultimate exports which is placed at 160 kilometres from Karachi and allied with metallic road. Its location is at south of Thatta \& south of Karachi but also appear in the proximity to Thar Coal Field \& linked with Karachi-Lahore Motorway and will be capable of providing numerous economic prosperity as it is under the parasol of SEZ and at the same time this range has the comparative advantage of skilled, semi-skilled labour force. In addition to this a new Jetty at Keti Bandar would intensify country's size of export of coal, plus the accruing of benefits to the about 5,000 people living all over this location. It would also lessen the cost of producing electricity to yield the competitiveness with transmission line which will hook up Bunder with Jamshoro and Matiari grids. In order to transport coal there would be a $235 \mathrm{~km}$ line and $190 \mathrm{~km}$ distant and road railway line from Islamkot to Keti Bandar and to connect Keti Bandar with Nooriabad respectively. Dhabeji SEZ spans over 1,000 acres and is about $55 \mathrm{~km}$ from Karachi at the Easter calibration of CPEC (N-5) or M-9 which has viability and evolution potential. Keti Bander SEZ stretches over 3,000 acres and is at $153 \mathrm{kms}$ from Karachi. Its industrial development potential would be realised after the construction of port and it is to be affiliated as MTD. By approving these, Sindh government require to work out for a plan which seem to be comprehensive plan and the expediency of the projects need to be in principle.

\section{ANALYSIS}

The whole project of CPEC is to combat the economic defiance for the sustainable development, which includes the provision of transit path for the trade of Pakistan with the rest of the world and this 2000 kilometer long corridor will also provide an ease to the Central-Asia Republics to create a predominant commercial relationship by trade with the various countries. Beside this fact that CPEC will be completed till 2030, if proceed uninterrupted, this is also an important aspect that this project is partially benefitting the provinces of Pakistan with respect to their priorities and need to expedite the economy and sustainable development of Pakistan. The CPEC energy projects are expected to be completed by 2020, ten years before the whole projects' completion and this shows the concern of energy generation in Pakistan, as it leads to the development of 


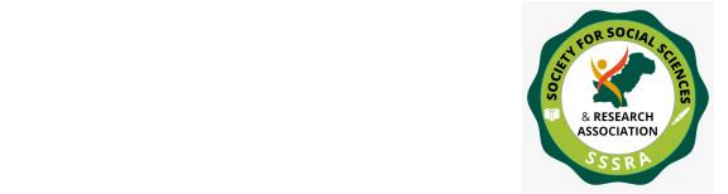

China - Pakistan Economic Corridor $\ldots . .$.

the industrial sector of Pakistan plus accommodating the hub of trade, Karachi. The Coal-fired project of Port Qasim, Karachi, Sindh is expected to generate $1320 \mathrm{MW}$ of electricity and will be completed till June 2018 which will be an extremely healthy contribution not only for the masses of Sindh but in turn will accommodate remaining provinces of Pakistan directly or indirectly through the advocacy of trade in the hub of trade, and in other words directly contribute for GDP growth of Pakistan. Other energy project of Sindh include, Engro Thar Coal-fired power plant, Mine Mouth Lignite Thar power project and Thar-Nova Mine Mouth Lignite Fired power project are excessively contributing similarly by generating $660 \mathrm{MW}, 33 \mathrm{MW}$, and $330 \mathrm{MW}$ respectively.

In addition to these four projects, the project of Thar is SMCF which is also expected to be in commercial operation in 2018/19. The Gharo, Thatta HWFP with $50 \mathrm{MW}$ installed capacity to generate energy with wind by using wind turbines was also expected to be in commercial operation till April, 2017, and proved the notion by this project's operation in commercial. The Jhimpir, Thatta wind-energy project is also in operation since 2017 as per estimated time of operation. The Sachal WPP of Sindh is also in operation since 2017. Two further Coal-energy projects are expected to be in operation till 2018/19. Two wind-power energy projects named Gorges II and Gorges III is also expected to be in commercial operation in 2018/19.few more energy projects of Sindh are also directly facilitating the other provinces and cities of Pakistan like Mitiari-Lahore ETP acquisition for converter station is completed and the project will be in commercial operation till 2018/19. The MMOPP and Surface Mine project are based on coal inputs is also in the process of getting its operation in commercial.

The facts and observations are exploring the ongoing schemes of Sindh Coal-based, Wind-power, Mine Mouth, MMOPP and few Transmission projects with the whole estimated cost of Rs. 4070.000 million and the allocation for 2017-18 is Rs. 1300.000 million. The final projection for the year 2018-19 is estimated about Rs.35.355 million with estimated amount for 2019-20 is not yet defined. Further we have observed that the schemes for Sindh energy is estimated for the cost of 


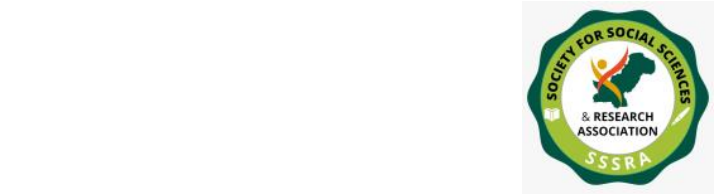

China - Pakistan Economic Corridor $\ldots . .$.

about Rs.6810.000 million with an allocation for the year 2017-18 of about Rs. 1705.000 million and the final projection for 2018-19 is about Rs.2552.500 million, but the projected cost for 2019-20 is not defined. As far as Sindh total energy schemes are concern, it is estimated that the cost is about Rs. 10884.000 million with an allocation of about Rs. 3005.000 million for 2017-18, and the final projection is about Rs. 2587.855 million for 2018-19, but the final projection of 2552.500 million is for 2019-20. The CPEC Sindh-energy projects are with huge potentials, as it is evident that Pakistan is the sixth most country in the world, population-wise, and this trend is hiking with soaring population, per-capita energy use, and industrialization and stand in need for total energy demand hike expected to triple or quadruple by 2025 .

The severe energy deficit in Pakistan is a hindrance for austere Economic and Development implications and also causes BOP deficit in the form of energy import costs to entertain energy shortfalls. The projected demand figures with outright current installed capacity of 24,474 MW, 36,217 MW, 54,359 MW, 80,566 MW and 1,13,695 MW in 2010, 2015, 2020, 2025 and 2030 respectively, which is obviously exploring the surge demand for energy consumption and require more potential to facilitate the same. This rising trend of energy's projected demand till 2030 is quiet more than the generation capacity of Pakistan highlighting the Gap of 6, $577 \mathrm{MW}, 18,320 \mathrm{MW}, 36,462 \mathrm{MW}, 62,669 \mathrm{MW}$ and 95,798 MW in the period for year 2010, 2015, 2020, 2025 and 2030 respectively.

The observation and studies explore the cost, Pakistan borne by load-shedding with estimated cost of Rs.157 billion to industrial sector and total cost to the economy due to industrial load-shedding is about Rs. 219 billion which is two percent (2\%) of GDP, and also causes loss of employment in the economy for about 400,000 number of workforce available and leads to the loss of international trade by a deficit of Rs. 75 billion worth exports. The intent of energy projects is to reduce the imports of furnance oil causing a huge deficit in BOP of Pakistan and create the opportunities to improve and determine the alternate and renewable energy options via developing Hydel projects too, plus utilize the idle resources such as Thar Coal with very huge potential of about 100, 


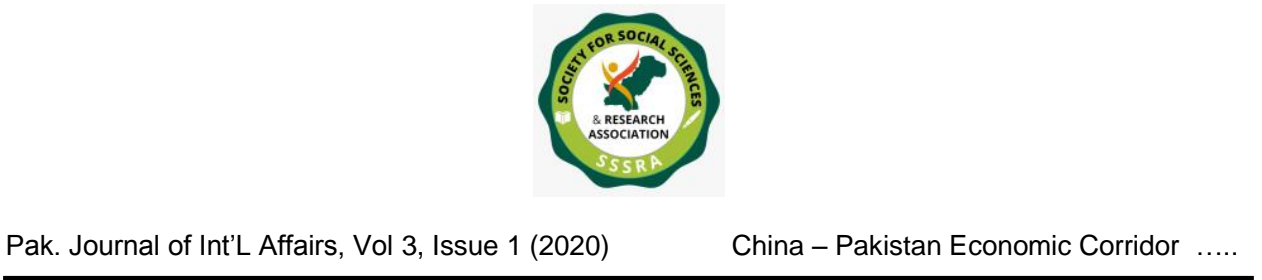

$000 \mathrm{MW}$ and enough resources to facilitate the country for more than three centuries.

The reserves of Coal in Pakistan are185 million tons, 457 million tons, 235 million tons, 217 million tons, and 90 million tons in Sindh, Punjab, Baluchistan and Khyber Pakhtoon Khuwah respectively. The per capita electricity generation in Pakistan according to 2008-09 and 2009-10 estimates are; $548 \mathrm{KWH}$, and $526.67 \mathrm{KWH}$, and per capita Gas consumption in 2008-09 and 2009-10 are 257.50 cubic meter and 252.24 cubic meter respectively. The estimated outlays and analysis shows that CPEC's all projects are immensely important for both China and Pakistan. On one hand these projects are to overcome Pakistan's economic, social and energy issues and on another hand serving China to expand periphery of influence, consolidation of global presence to emerge China as global leader. This corridor is a path to trade and route of energy generation and transmission. The routes establishing via CPEC will also curtail path and cost-effective for China to get access to the Middle-East and North Africa market along with rest of the world and the same corridor will strengthen the Pakistan via development and energy generation and transmission across the nations and also across the provinces of Pakistan by emphasizing on its domain of trade located inside Sindh province.

\section{CONCLUSION}

The challenges whether internal or external, require Pakistan to opt for a game change strategy and CPEC, in this regard, has huge potential to do so. The multi-billion dollars CPEC projects aim to develop infrastructure, enhance international trade via low transit cost, raise regional connectivity and the low-cost energy generation and transmission in Pakistan especially in Sindh where we have the hub of Pakistan trade.

In addition to these economic benefits, the CPEC is estimated to enhance the national security through this partnership which will be fruitful for the long-term regional connectivity and improved Trade and Development plus Defense matters, because China is population-wise the largest country of the world and also getting further sound economically which leads to 
high energy and consumer goods and services demanding country of the world and biggest importer of Pakistan's marble industry; therefore uninterrupted power generation and transmission will facilitate this further expected high demand for all industrial goods and services by China and rest of the world at the same time and also strengthen the national image of Pakistan in the eyes of the world.

\section{REFERENCES}

Abid, M., \& Ashfaq, A. (2015). CPEC: Challenges and opportunities for Pakistan. Journal of Pakistan Vision, 16(2), 142-169.

Ali, S. (2016, December 30). Three Major Sindh Project Make way into CPEC. The Nation https://nation.com.pk/30-Dec-2016/three-majorsindh-projects-make-way-into-cpec

Associated Press of Pakistan, (2016). Sindh Largest Recipient Of Energy

Projects Under CPEC, https://www.app.com.pk/pak-chinarelations/pak-china-relations/sindh-largest-recipient-of-energyprojects-under-cpec/

Chaudhry, M. G. (1994). Pakistan, Ministry of Finance, Revenue and Economic Affairs. Report of Prime Minister's Task Force on Agriculture.

China Pakistan Economic Corridor CPEC. http://cpec.gov.pk/

Dilawar, I. (2017, April 13). China's Silk Road Push in Pakistan Edges Out U.S. Investments. Bennett, Coleman \& Co. Ltd. https://www.bloomberg.com/news/articles/2017-04-12/china-s-silkroad-push-in-pakistan-edges-out-u-s-investments

Federal; Bureau of Statistics, Government of Pakistan. http://www.pbs.gov.pk/ 
Gao, B. (2013). From Maritime Asia to Continental Asia: China's Responses to the Challenge of the Trans-Pacific Partnership, Duke University, 2013.

Government of Sindh, Officials. https://www.sindh.gov.pk/

Haq, R., \& Farooq, N. (2016). Impact of CPEC on social welfare in Pakistan: A district level analysis. The Pakistan Development Review, 597-618.

Husain, K. (2017, June 12). Exclusive: CPEC master plan revealed, Daily Dawn. https://www.dawn.com/news/1333101

Institute of Public Policy (2008). State of the Economy - Emerging from Crisis. Estimates listed in Beacon House National University Publication.

Khan, K., Khan, K., \& Anwar, S. (2016). Special economic zones (SEZs) and CPEC: Background, challenges and strategies. The Pakistan Development Review, 203-216.

Ministry of Energy. Power Division Government of Pakistan (2017) http://www.mowp.gov.pk/

Ministry of Planning \& Development, Government of Pakistan. https://www.pc.gov.pk/

Mustikhan, A. (2017, May 8). Is CPEC also a game changer for Balochistan? : Federal government must revisit its plans while Balochistan should tap this one-time opportunity. The Express, Tribune. https://tribune.com.pk/story/1404001/cpec-also-gamechanger-balochistan

PEPCO, Government of Sindh, Pakistan , (2012). https://www.reep.org/pakistan-2012

Rafiq, K. (2017) CPEC - A Journey To Prosperity, The Nation,. 
https://nation.com.pk/28-Jan-2017/cpec-a-journey-to-prosperity

Ramay, S. A. (2016). CPEC: A Chinese dream being materialized through Pakistan. Sustainable Development Policy Institute, Pakistan.

Saleem, A. H. (2016). CPEC and Export Performance of Pakistan, China Pakistan Study Centre, Institute of Strategic Study Islamabad. http://issi.org.pk/issue-brief-on-cpec-and-export-performance-ofpakistan/.

Tong, L. (2014). CPEC industrial zones and China-Pakistan capacity cooperation. Strategic Studies, 34, 174-184.

Zhiqin, S., \& Yang, L. (2016). The Benefits and Risks of the ChinaPakistan Economic Corridor. Carnegie-Tsinghua Center for Global Policy, December, 21. 


\section{ACRONYMS}

\begin{tabular}{|l|l|}
\hline AEDB & Alternative Energy Development Board \\
\hline BOP & Balance of Payment \\
\hline CBPP & Coal based power project \\
\hline CETL & China Electric Power Equipment and Technology Co. Ltd. \\
\hline CFPP & Coal-fired power plant \\
\hline CMEC & China Machinery Engineering Corporation \\
\hline COD & Commercial operation date \\
\hline CSCEC & China State Construction Engineering Corporation \\
\hline ETP & Energy Transmission Projects \\
\hline EDZ & Economic Development Zone \\
\hline FC & Financial closed \\
\hline FTZ & Free trade zone \\
\hline GDP & Gross Domestic Product \\
\hline GES & Grounding Electrode Stations \\
\hline GoP & Government of Pakistan \\
\hline HDPPL & Hydro China Dawood Power Pvt. Limited \\
\hline HWFP & Hydro wind farm Project \\
\hline IP & Iran-Pakistan \\
\hline IPP & Independent Power Producer \\
\hline ITC & Independent Transmission Company \\
\hline LMI & Lower-middle-income \\
\hline MMOPP & Mine Mouth Oracle Power Plant \\
\hline MTD & Medium-term project \\
\hline MMLF & Mine Mouth Lignite Fired \\
\hline NTDC & National Transmission \& Dispatch Company \\
\hline P\&D & Planning \& Development \\
\hline PDR & Planning, Development and Reforms \\
\hline PPIB & Private Power and Infrastructure Board \\
\hline P\&NR & Petroleum and Natural Resources \\
\hline SECMC & Sindh Engro Coal Mining Company \\
\hline SEPCL & Shanghai Electric Power Company Limited \\
\hline SEZ & Special Economic Zone \\
\hline SGCC & State Grid Corporation of China \\
\hline SMP & Surface Mine Project \\
\hline SMCF & Surface Mine Coal-field \\
\hline TCEB & Thar Coal Energy Board \\
\hline WPP & Wind Power Project \\
\hline
\end{tabular}




\begin{tabular}{|l|l|}
\hline TLP & Transmission Line Project \\
\hline T\&D & Trade and Development \\
\hline UMI & Upper-middle-income \\
\hline W\&P & Water and Power \\
\hline WPP & Wind Power Plant \\
\hline
\end{tabular}

